\title{
Aktivitas olahraga bulu tangkis dan respon perubahan asam urat darah usia produktif
}

\author{
Angkit Kinasih ${ }^{1}$, Ronaldo Lomi Djara ${ }^{1}$, Ferry Fredy Karwur ${ }^{2 *}$ \\ ${ }^{1}$ Program Studi Pendidikan Jasmani Kesehatan dan Rekreasi, Universitas Kristen Satya Wacana. Jalan \\ Diponegoro 52-60, Salatiga 50711, Indonesia. \\ ${ }^{2}$ Program Studi Gizi, Fakultas Kedokteran dan Ilmu Kesehatan, Universitas Kristen Satya Wacana. \\ Jalan Diponegoro 52-60, Salatiga 50711, Indonesia. \\ * Coressponding Author. E-mail: ferry.karwur@uksw.edu
}

Received: August 19, 2021; Accepted: September 14, 2021; Published: September 25, 2021

\begin{abstract}
Abstrak: Penelitian ini bertujuan untuk mengetahui ada tidaknya respon perubahan pada kadar asam urat akibat aktivitas olahraga bulu tangkis. Desain penelitian ini adalah quasi eksperimen. Sampel yang digunakan sebanyak delapan responden dengan kriteria tertentu. Perlakukan aktivitas fisik dilakukan dua kali pada hari yang berbeda dengan 4 kali pengukuran kadar asam urat. Metode penelitian yang digunakan adalah repeated measure analysis. Ketika subyek diukur berulang kali dengan jumlah yang sedikit per percobaan maka repeated measures analysis dapat digunakan. Hasil penelitian menunjukkan bahwa perlakukan olahraga bulu tangkis memberikan respon perubahan yang signifikan terhadap perubahan kadar asam urat dengan nilai probabilitas sebesar 0,038. Hasil ini diperoleh dengan menggunakan uji Greenhouse-Geisser dimana asumsi normalitas dan homogenitas telah terpenuhi. Pada hasil uji marginal menggunakan pairwise comparisons, terdapat perbedaan yang signifikan pada rata-rata kadar asam urat 15 menit setelah olahraga dan jam 09.00 hari berikutnya, dimana terjadi penurunan sebesar $1,169 \mathrm{mg} / \mathrm{dl}$. Olahraga bulu tangkis dapat menurunkan kadar asam urat yang ditandai dengan adanya penurunan sebesar $0,15 \mathrm{mg} / \mathrm{dl}$ pada jam 09.00 hari berikutnya dibandingkan dengan sebelum olahraga. Secara marginal, penurunan ini tidak signifikan secara statistik, namun olahraga bulu tangkis yang rutin dapat menjadi salah satu pilihan aktifitas fisik bagi yang ingin menurunkan kadar asam urat.
\end{abstract}

Kata Kunci: kadar asam urat, olahraga bulu tangkis, repeated measure analysis, greenhouse-geisser

\section{The sports activity of badminton and responses to changes in blood uric acid at productive age}

\begin{abstract}
This study aims to determine whether there was a response to changes in uric acid levels due to the physical activity of badminton. The design of this study is a quasi-experimental. The sample used in this study was eight respondents with certain criteria. Treat physical activity twice on different days with 4 measurements of uric acid levels. The method of this study is repeated measure analysis. When subjects are measured repeatedly, requiring fewer subjects per experiment, then repeated measures analysis can be used. The results showed that the treatment of badminton had a significant effect on changes in uric acid levels with a probability value of 0,038. These results were obtained by using the Greenhouse-Geisser test where the assumptions of normality and homogeneity were satisfied. From the marginal test results using pairwise comparisons, there was a significant difference in the average uric acid levels at 15 minutes after exercise and 9 hours the following day, where there was a decrease of $1.169 \mathrm{mg} / \mathrm{dl}$. Badminton can reduce uric acid levels, which is indicated by a decrease of $0.15 \mathrm{mg} / \mathrm{dl}$ at 09.00 the next day compared to before exercise. Marginally, this decrease is not statistically significant, but regular badminton can be an option for physical activity for those who want to reduce uric acid levels.
\end{abstract}

Keywords: uric acid levels, badminton, repeated measure analysis, greenhouse-geisser.

How to Cite: Kinasih, A., Djara, R. I., \& Karwur, F. F. (2021). Aktivitas olahraga bulu tangkis dan respon perubahan asam urat darah usia produktif, Jurnal keolahragaan, 9(2), 279-289. doi: https://doi.org/10.21831/jk.v9i2.43271 
Jurnal Keolahragaan 9 (2), 2021 - 280

Angkit Kinasih, Ronaldo Lomi Djara, Ferry Fredy Karwur

\section{PENDAHULUAN}

Undang-Undang nomor 36 tahun 2009 tentang kesehatan merumuskan bahwa "sehat adalah keadaan baik secara mental, fisik, sosial, maupun spiritual yang memungkinkan seseorang untuk hidup produktif secara sosial dan ekonomis; dan bugar adalah "kemampuan tubuh seseorang dalam melakukan kegiatannya sehari-hari dengan tubuh yang penuh energi, dan setelah menyelesaikan kegiatannya seorang yang bugar masih memiliki tenaga cadangan dan semangat untuk menikmati waktu senggangnya, serta siap untuk melakukan kegiatannya lain yang tidak terduga atau kegiatan-kegiatan yang mendadak (P2PTM Kemenkes RI, 2021). Undang-undang No.36 Tahun 2009 tentang kesehatan selanjutnya menyatakan bahwa kebugaran jasmani dan peningkatan derajat kesehatan pada masyarakat yang dapat dilakukan yaitu melalui latihan fisik, aktivitas fisik, dan olahraga. Aktivitas fisik dapat meningkatkan kekuatan otot dan tulang, meningkatkan fleksibilitas, keseimbangan, serta kebugaran (Wicaksono, 2020).

Dalam kehidupan sehari-hari, ada banyak bentuk aktivitas fisik, antara lain: menyapu, menyiram halaman, dan jalan kaki (Fikri, 2017). Terdapat pula aktivitas fisik yang dirancang secara teratur dan terencana, seperti olahraga aerobik, dengan beragam jenis, antara lain kegiatan olahraga bulu tangkis, sepakbola, dan renang (Fikri, 2017). Bulu tangkis merupakan salah satu dari sekian banyak cabang olahraga yang sangat populer di negara Indonesia karena bulu tangkis termasuk dalam olahraga prestasi (Muthiarani et al., 2021). Olahraga bulu tangkis juga merupakan olahraga yang dapat dimainkan oleh semua lapisan masyarakat, seperti anak-anak, orang dewasa, laki-laki maupun perempuan (Putra \& Sugiyanto, 2016). Aktivitas fisik olahraga yang tepat sering dikaitkan dengan meningkat kemampuan antioksidasi dan immunitas tubuh. Namun demikian, dari beragam kegiatan olahraga, sering kita jumpai bahwa kegiatan itu dilakukan melampaui maksudnya untuk mencapai kesehatan dan kebugaran. Olahraga yang berat dan berlebihan menciptakan cekaman oksidatif di otot dan pembulu darah, dan memicu inflamasi berlebihan (Powers et al., 2016).

Asam urat adalah sisa metabolisme zat purin dari makanan yang dikonsumsi (Andriani \& Chaidir, 2016). Asam urat memiliki fungsi penting sebagai antioksidan hidrofilik utama plasma darah (Ames et al., 1981) dan pada cairan cerebrospinal fluid (Bowman et al., 2010). Fungsi antioksidasi asam urat di cairan cerebrospinal ditopang oleh kenyataan bahwa kadar asam urat di dalam tubuh terlalu rendah (hipourisemia: $<2,5 \mathrm{mg} / \mathrm{dl}$ ) menyebabkan sejumlah penyakit degenaratif seperti Parkinson. Namun sebaliknya, asam urat yang terlalu tinggi justru memicu sejumlah penyakit inflamatif, sebagaimana terjadi pada penyakit kardiovaskuler (Feig; et al., 2008) dan artritis gout (Choi et al., 2005). Kurangnya aktivitas fisik dan pola makan yang tidak seimbang dapat menyebabkan tingginya asam urat dalam darah yang mengakibatkan gangguan hiperurisemia yang akan menimbulkan penyakit artritis gout dan gout nefropati (Darmawan et al., 2016).

Dalam keadaan sehat, kadar asam urat pada manusia dipertahankan pada kadar yang normal, yakni pada kadar antara $2,6 \mathrm{mg} / \mathrm{dl} \mathrm{s} / \mathrm{d} 6,5 \mathrm{mg} / \mathrm{dl}$ pada Wanita pre-menopause, dan sedikit lebih tinggi pada pria, yakni $3.5 \mathrm{mg} / \mathrm{dl} \mathrm{s} / \mathrm{d} 7,2 \mathrm{mg} / \mathrm{dl}$ (Desideri et al., 2014). Itulah sebabnya, asam urat dalam rentang normal dapat mengurangi cekaman yang dipicuh olahraga (Waring et al., 2003). Sebaliknya, hiperurisemia (>7.0 mg/dl) dapat memicuh aktivasi sistem kekebalan ke arah lintasan pro-inflamasi (Joosten et al., 2020). Dengan demikian, naik-turunnya asam urat darah pada kisaran normal dapat merupakan bioindikator respons fitness aktivitas fisik dan olahraga.

Pengukuran fitness metabolic (metabolic fitness) sangat penting untuk mengetahui positiftidaknya suatu kegiatan fisik dan/atau olahraga. Pengukuran fitness metabolik antara lain dilakuan dengan melakukan pengukuran rasio antara kapasitas mitokondria dalam menggunakan substrat dengan kapasitas maksimum dari otot dalam mengundu oksigen (oxygen uptake of the muscle) (Saltin \& Pilegaard, 2002), pengunduan oksigen maksimum (maximal oxygen uptake; VO2max), utilisasi fraksional VO2max, batas ambang kadar laktat (LT) dan oxygen cost of running (CR) (Conley \& Krahenbuhl, 1980; Pate \& Kriska, 1984; Rabadán et al., 2011). Namun demikian, mengukur hubungan antara metabolic fitness dengan aktivitas olahraga menemui persoalannya di dalam derajat prisisinya (Laye et al., 2015; Lee et al., 2011).

Pengukuran asam urat plasma darah telah merupakan prosedur yang umum dan sederhana, dan kadar asam urat juga merupakan indikator metabolik terkait banyak penyakit, terutama aktivasi inflamasi oleh banyak sebab, seperti oleh peningkatan aktivitas otot (Agostini et al., 2004), dan sebagai sinyal bahaya imunologis (Martinon, 2008). Dengan demikian, naik-turunnya kadar asam urat sebelum 
dan setelah olahraga dapat digunakan atau dikembangkan sebagai indikator metabolic fitness dalam kegiatan olahraga atau aktivitas fisik lainnya yang lebih bersifat umum. Oleh sebab itu, penelitian ini ingin mengetahui pengaruh aktivitas fisik terhadap naik-turunnya kadar asam urat pada mahasiswa usia muda dengan IMT overweight, sebelum dan setelah melakukan aktivitas olahraga, dengan menganalisis perbedaan kadar asam urat sebelum dan setelah melakukan aktivitas olahraga bulu tangkis pada mahasiswi di Universitas Kristen Satya Wacana.

\section{METODE}

Penelitian ini merupakan penelitian fisibililitas untuk persiapan penelitian eksperimental dengan desain quasi eksperimen atau juga disebut non-randomized controlled trial (non-RCT). Penelitian quasi eksperimen adalah penelitian yang melakukan uji coba dengan suatu intervensi pada sekelompok subyek dengan atau tanpa suatu kelompok pembanding namun peneliti tidak melakukan randomisasi ketika memasukkan subyek ke dalam kelompok control atau perlakukan (Azhari, 2017). Penelitian dilakukan di Gor PPLP Salatiga dengan pengambilan sampel menggunakan metode consecutive sampling dimana semua subyek penelitian adalah yang memenuhi kriteria. Partisipan dalam penelitian ini sebanyak delapan (8) mahasiswi di Universitas Kristen Satya Wacana (UKSW) Salatiga yang tidak rutin melakukan olahraga bulu tangkis. Kriteria responden dalam penelitian ini adalah perempuan berusia 1825 tahun, memiliki Indeks Massa Tubuh (IMT) $25-27 \mathrm{Kg} / \mathrm{m}^{2}$, setiap responden dalam keadaan sehat dan tidak sedang mengalami sakit misalnya demam, flu atau sakit lainnya, serta bersedia menjadi sampel penelitian. Responden penelitian diberikan intervensi aktivitas fisik (olahraga bulu tangkis) selama 1 minggu, dimana aktivitas fisik tersebut dilakukan dengan 2 kali pertemuan yaitu pada tanggal 04 dan 11 Oktober 2020. Berikut adalah skema aktivitas fisik:

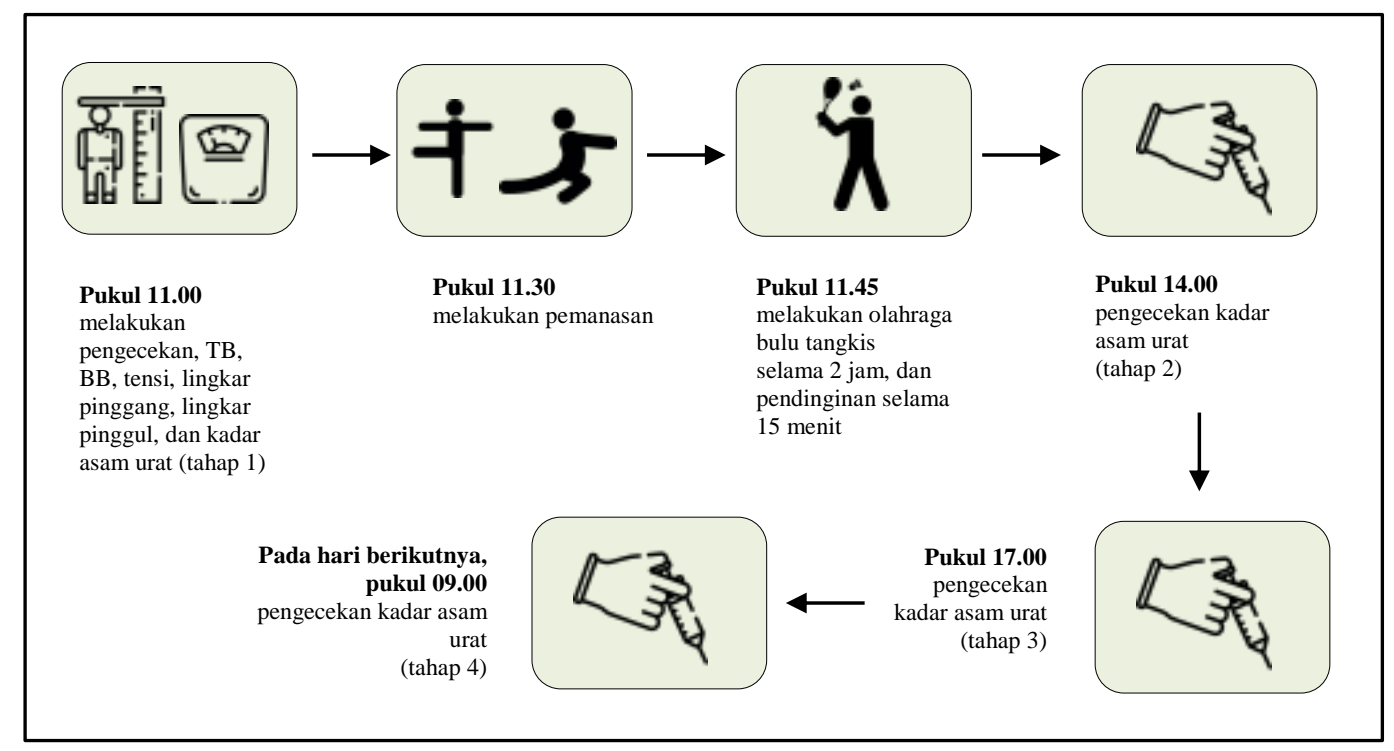

Gambar 1. Skema Aktivitas Fisik

Metode analisis yang dilakukan dalam penelitian ini adalah repeated measures analysis. Ketika subyek diukur berulang kali dengan subyek yang sedikit per percobaan maka repeated measures analysis dapat digunakan (Ho, 2014). repeated measures analysis merupakan bagian dari statistik parametrik sehingga nilai standardized residual untuk semua pengukuran harus memenuhi asumsi normal. Pada kasus ketika jumlah sampel kecil, maka uji normalitas dapat menggunakan Kolmogorovsmirnov dan ketika jumlah sampel besar, maka uji shapiro-wilk dapat digunakan. Selain asumsi normalitas, salah satu asumsi yang perlu diperhatikan adalah asumsi homogenitas yang dapat diuji menggunakan Mauchly's Test of Sphericity yang merupakan bagian dari repeated measure analysis (Ho, 2014). Hasil yang diharapkan pada kedua uji asumsi ini tidak terletak pada hipotesis alternatif, sehingga nilai probabilitas yang diharapkan adalah lebih dari taraf signifikan yang ditentukan. Taraf signifikansi alpha yang digunakan dalam menguji hipotesis adalah sebesar 0,05 . 
Uji signifikansi pada Mauchly's Test of Sphericity menentukan analisis pada tahap selanjutnya. Jika nilai probabilitas pada Mauchly's Test of Sphericity lebih dari 0,05 maka test of within subject effects dapat dilakukan (Ho, 2014). Pada tabel test of within subject effects terdapat uji GreenhouseGeisser, dimana uji ini memiliki hipotesis alternatif: ada perbedaan rata-rata kadar asam urat pada keempat kelompok waktu pengukuran, sehingga diharapkan hasil uji memiliki nilai probabilitas yang kurang dari taraf signifikansi (alpha) 0,05. Selanjutnya untuk mengetahui secara marginal perbedaan rata-rata kadar asam urat pada ke-empat waktu pengukuran maka digunakan pairwise comparison.

\section{HASIL DAN PEMBAHASAN}

Karakteristik partisipan dalam penelitian ini dapat dilihat pada tabel 1, dimana usia partisipan ada dalam rentang 18 sampai 24 , dengan rata-rata tinggi badan $158,875 \mathrm{~cm}$, rata-rata berat badan $65,5 \mathrm{~kg}$, rata-rata indeks masa tubuh (IMT) $25,875 \mathrm{~kg} / \mathrm{m}^{2}$, rata-rata lingkar pinggang $80 \mathrm{~cm}$, rata-rata lingkar pinggul 97,125 cm, dan rata-rata RLPP sebesar 0,825. Dilihat dari hasil pendeteksian nilai ekstrim, rentang nilai pada setiap data karakteristik partisipan berada dalam rentang nilai ekstrim. Hal ini menunjukkan bahwa tidak terdapat nilai ekstrim pada keseluruhan data karakteristik partisipan. Contoh pada data indeks masa tubuh (IMT) yang memiliki nilai minimum 25 dan maksimum $27 \mathrm{~kg} / \mathrm{m}^{2}$, dimana rentang nilai ini berada dalam rentang hasil pendeteksian nilai ekstrim yaitu 23,37 sampai dengan 28,38 $\mathrm{kg} / \mathrm{m}^{2}$. Hal ini menunjukkan bahwa tidak terdapat nilai ekstrim pada data indeks masa tubuh.

Tabel 1. Analisis Deskriptif Karakeristik Partisipan

\begin{tabular}{lcccccc}
\hline & Minimum & Maksimum & $\begin{array}{c}\text { Rata-rata } \\
(\bar{x})\end{array}$ & $\begin{array}{c}\text { Standar } \\
\text { deviasi (SD) }\end{array}$ & $\bar{x}-3 *$ SD & $\bar{x}+3 *$ SD \\
\hline Usia & 18 & 24 & 21 & 1.96 & 15.25 & 27.00 \\
TB $(\mathrm{cm})$ & 148 & 170 & 158.9 & 6.40 & 139.67 & 17.08 \\
BB $(\mathrm{kg})$ & 55 & 78 & 65.5 & 6.48 & 46.06 & 84.94 \\
IMT $\left(\mathrm{kg} / \mathrm{m}^{2}\right)$ & 25 & 27 & 25.9 & 0.83 & 23.37 & 28.38 \\
LP $(\mathrm{cm})$ & 73 & 93 & 80 & 6.46 & 60.62 & 99.38 \\
LPi $(\mathrm{cm})$ & 89 & 110 & 97.1 & 6.47 & 77.72 & 116.53 \\
RLPP & 0,7 & 0,9 & 0.8 & 0.04 & 0.62 & 0.87 \\
\hline
\end{tabular}

Pengambilan data kadar asam urat dilakukan pada tanggal 4 Oktober (U1) dan tanggal 11 Oktober (U2). Pengambilan data dilakukan saat sebelum olahraga, 15 menit setelah olahraga, 3 jam setelah olahraga, dan jam 9 hari berikutnya. Pada tabel 2, rata-rata kadar asam urat sebelum olahraga adalah sebesar 6,16 mg/dl dengan nilai SD 1,17 yang kemudian meningkat menjadi 7,18 mg/dl dengan nilai SD 1,37 saat 15 menit setelah olahraga usai. Peningkatan kadar asam urat terjadi sesaat setelah usai berolahraga, namun kadar asam urat responden mengalami penurunan hingga $6,01 \mathrm{mg} / \mathrm{dl}$ dengan nilai SD 0,82 pada jam 9 hari berikutnya.

Pada gambar 2, grafik batang memperlihatkan rata-rata kadar asam urat pada setiap perlakuan, dimana rata-rata kadar asam urat tertinggi terjadi saat 15 menit setelah olahraga. Kemudian dari tinggi pendeknya error bar mean $\pm 0.5 \mathrm{SD}$ memperlihatkan lebar sempitnya confident interal untuk nilai ratarata. Error bar tertinggi terjadi pada saat 15 menit setelah olahraga yang kemudian semakin mengecil pada jam 9 keesokan harinya. Hal ini menunjukkan bahwa adanya perlakuan aktivitas olahraga memberikan respon pada kenaikan kadar asam urat saat 15 menit setelah olahraga, yang membuat sebaran data kadar asam urat semakin jauh dari nilai rata-ratanya, yang ditunjukkan dengan confident interval yang semakin melebar. Namun kemudian semakin mendekati nilai rata-ratanya setelah beristirahat, dimana pada titik ini confident interval rata-rata kadar asam urat semakin menyempit.

Tabel 2. Kadar asam urat partisipan sebelum dan setelah olahraga bulu tangkis

\begin{tabular}{|c|c|c|c|c|c|c|c|c|c|c|c|c|}
\hline \multirow{2}{*}{$\begin{array}{l}\text { Partisi } \\
\text { pan }\end{array}$} & \multicolumn{3}{|c|}{ Sebelum Or } & \multicolumn{3}{|c|}{15 Menit Setelah Or } & \multicolumn{3}{|c|}{3 Jam Setelah Or } & \multicolumn{3}{|c|}{ Jam 9 Hari Berikutnya } \\
\hline & U1 & $\mathrm{U} 2$ & $\begin{array}{c}\text { Rata- } \\
\text { rata }\end{array}$ & U1 & $\mathrm{U} 2$ & $\begin{array}{c}\text { Rata- } \\
\text { rata }\end{array}$ & U1 & $\mathrm{U} 2$ & $\begin{array}{c}\text { Rata- } \\
\text { rata }\end{array}$ & $\mathrm{U} 1$ & $\mathrm{U} 2$ & $\begin{array}{c}\text { Rata- } \\
\text { rata }\end{array}$ \\
\hline $\mathrm{R}_{2}{ }_{2}^{2}$ & $\begin{array}{c}6,5 \\
0\end{array}$ & 6,50 & 6,50 & $\begin{array}{c}7,7 \\
0\end{array}$ & $\begin{array}{c}9,4 \\
0\end{array}$ & 8,55 & $\begin{array}{c}6,6 \\
0\end{array}$ & $\begin{array}{c}5,7 \\
0\end{array}$ & 6,15 & $\begin{array}{c}6,0 \\
0\end{array}$ & $\begin{array}{c}6,0 \\
0\end{array}$ & 6,00 \\
\hline $\begin{array}{c}\mathrm{R} 2 \_2 \\
0\end{array}$ & $\begin{array}{c}5,8 \\
0\end{array}$ & 5,80 & 5,80 & $\begin{array}{c}7,3 \\
0\end{array}$ & $\begin{array}{c}5,9 \\
0\end{array}$ & 6,60 & $\begin{array}{c}7,4 \\
0\end{array}$ & $\begin{array}{c}6,4 \\
0\end{array}$ & 6,90 & $\begin{array}{c}7,6 \\
0\end{array}$ & $\begin{array}{c}5,7 \\
0\end{array}$ & 6,65 \\
\hline
\end{tabular}


Jurnal Keolahragaan 9 (2), 2021 - 283

Angkit Kinasih, Ronaldo Lomi Djara, Ferry Fredy Karwur

\begin{tabular}{|c|c|c|c|c|c|c|c|c|c|c|c|c|}
\hline \multirow{2}{*}{$\begin{array}{l}\text { Partisi } \\
\text { pan }\end{array}$} & \multicolumn{3}{|c|}{ Sebelum Or } & \multicolumn{3}{|c|}{15 Menit Setelah Or } & \multicolumn{3}{|c|}{3 Jam Setelah Or } & \multicolumn{3}{|c|}{ Jam 9 Hari Berikutnya } \\
\hline & $\mathrm{U} 1$ & $\mathrm{U} 2$ & $\begin{array}{c}\text { Rata- } \\
\text { rata }\end{array}$ & $\mathrm{U} 1$ & $\mathrm{U} 2$ & $\begin{array}{c}\text { Rata- } \\
\text { rata }\end{array}$ & $\mathrm{U} 1$ & $\mathrm{U} 2$ & $\begin{array}{c}\text { Rata- } \\
\text { rata }\end{array}$ & U1 & $\mathrm{U} 2$ & $\begin{array}{c}\text { Rata- } \\
\text { rata }\end{array}$ \\
\hline $\begin{array}{c}\text { R3_1 } \\
9\end{array}$ & $\begin{array}{c}6,0 \\
0\end{array}$ & 6,60 & 6,30 & $\begin{array}{c}8,7 \\
0\end{array}$ & $\begin{array}{c}8,3 \\
0\end{array}$ & 8,50 & $\begin{array}{c}7,6 \\
0\end{array}$ & $\begin{array}{c}7,3 \\
0\end{array}$ & 7,45 & $\begin{array}{c}6,8 \\
0\end{array}$ & $\begin{array}{c}5,7 \\
0\end{array}$ & 6,25 \\
\hline $\begin{array}{c}\mathrm{R} 4 \_1 \\
8\end{array}$ & $\begin{array}{c}5,0 \\
0\end{array}$ & 4,10 & 4,55 & $\begin{array}{c}5,7 \\
0\end{array}$ & $\begin{array}{c}4,9 \\
0\end{array}$ & 5,30 & $\begin{array}{c}5,7 \\
0\end{array}$ & $\begin{array}{c}5,7 \\
0\end{array}$ & 5,70 & $\begin{array}{c}5,0 \\
0\end{array}$ & $\begin{array}{c}4,9 \\
0\end{array}$ & 4,95 \\
\hline $\mathrm{R}_{2}{ }^{2}$ & $\begin{array}{c}7,6 \\
0\end{array}$ & 8,70 & 8,15 & $\begin{array}{c}6,5 \\
0\end{array}$ & $\begin{array}{c}6,6 \\
0\end{array}$ & 6,55 & $\begin{array}{c}7,0 \\
0\end{array}$ & $\begin{array}{c}6,3 \\
0\end{array}$ & 6,65 & $\begin{array}{c}7,6 \\
0\end{array}$ & $\begin{array}{c}6,5 \\
0\end{array}$ & 7,05 \\
\hline $\mathrm{R}_{4} \_2$ & $\begin{array}{c}5,0 \\
0\end{array}$ & 5,70 & 5,35 & $\begin{array}{c}5,7 \\
0\end{array}$ & $\begin{array}{c}6,0 \\
0\end{array}$ & 5,85 & $\begin{array}{c}3,7 \\
0\end{array}$ & $\begin{array}{c}4,9 \\
0\end{array}$ & 4,30 & $\begin{array}{c}5,0 \\
0\end{array}$ & $\begin{array}{c}4,9 \\
0\end{array}$ & 4,95 \\
\hline${ }_{2}^{\mathrm{R} 7 \_2}$ & $\begin{array}{c}5,0 \\
0\end{array}$ & 5,60 & 5,30 & $\begin{array}{c}5,9 \\
0\end{array}$ & $\begin{array}{c}8,1 \\
0\end{array}$ & 7,00 & $\begin{array}{c}6,2 \\
0\end{array}$ & $\begin{array}{c}8,0 \\
0\end{array}$ & 7,10 & $\begin{array}{c}5,9 \\
0\end{array}$ & $\begin{array}{c}5,0 \\
0\end{array}$ & 5,45 \\
\hline $\begin{array}{c}\text { R8_2 } \\
2\end{array}$ & $\begin{array}{c}7,6 \\
0 \\
\end{array}$ & 7,00 & 7,30 & $\begin{array}{c}9,3 \\
0 \\
\end{array}$ & $\begin{array}{c}8,8 \\
0 \\
\end{array}$ & 9,05 & $\begin{array}{c}9,4 \\
0 \\
\end{array}$ & $\begin{array}{c}6,5 \\
0 \\
\end{array}$ & 7,95 & $\begin{array}{c}6,5 \\
0 \\
\end{array}$ & $\begin{array}{c}7,0 \\
0 \\
\end{array}$ & 6,75 \\
\hline Total & $\begin{array}{c}48 \\
5\end{array}$ & $\begin{array}{c}50,0 \\
0\end{array}$ & 49,25 & $\begin{array}{c}56 \\
8\end{array}$ & $\begin{array}{c}58, \\
0\end{array}$ & 57,40 & $\begin{array}{c}53 \\
6\end{array}$ & $\begin{array}{c}50 \\
8\end{array}$ & 52,20 & $\begin{array}{c}50 \\
4\end{array}$ & $\begin{array}{c}45 \\
7\end{array}$ & 48,05 \\
\hline $\begin{array}{l}\text { Rata- } \\
\text { rata }\end{array}$ & $\begin{array}{c}6,0 \\
6\end{array}$ & 6,25 & 6,16 & $\begin{array}{c}7,1 \\
0\end{array}$ & $\begin{array}{c}7,2 \\
5\end{array}$ & 7,18 & $\begin{array}{c}6,7 \\
0\end{array}$ & $\begin{array}{c}6,3 \\
5\end{array}$ & 6,53 & $\begin{array}{c}6,3 \\
0\end{array}$ & $\begin{array}{c}5,7 \\
1\end{array}$ & 6,01 \\
\hline SD & $\begin{array}{c}1,0 \\
9\end{array}$ & 1,33 & 1,17 & $\begin{array}{c}1,3 \\
9\end{array}$ & $\begin{array}{c}1,6 \\
1\end{array}$ & 1,37 & $\begin{array}{c}1,6 \\
4\end{array}$ & $\begin{array}{c}0,9 \\
7\end{array}$ & 1,14 & $\begin{array}{c}1,0 \\
2\end{array}$ & $\begin{array}{c}0,7 \\
7\end{array}$ & 0,82 \\
\hline Min & 5 & 4.1 & 4.55 & 5.7 & 4.9 & 5.3 & 3.7 & 4.9 & 4.3 & 5 & 4.9 & 4.95 \\
\hline Maks & 7.6 & 8.7 & 8.15 & 9.3 & 9.4 & 9.05 & 9.4 & 8 & 7.95 & 7.6 & 7 & 7.05 \\
\hline
\end{tabular}

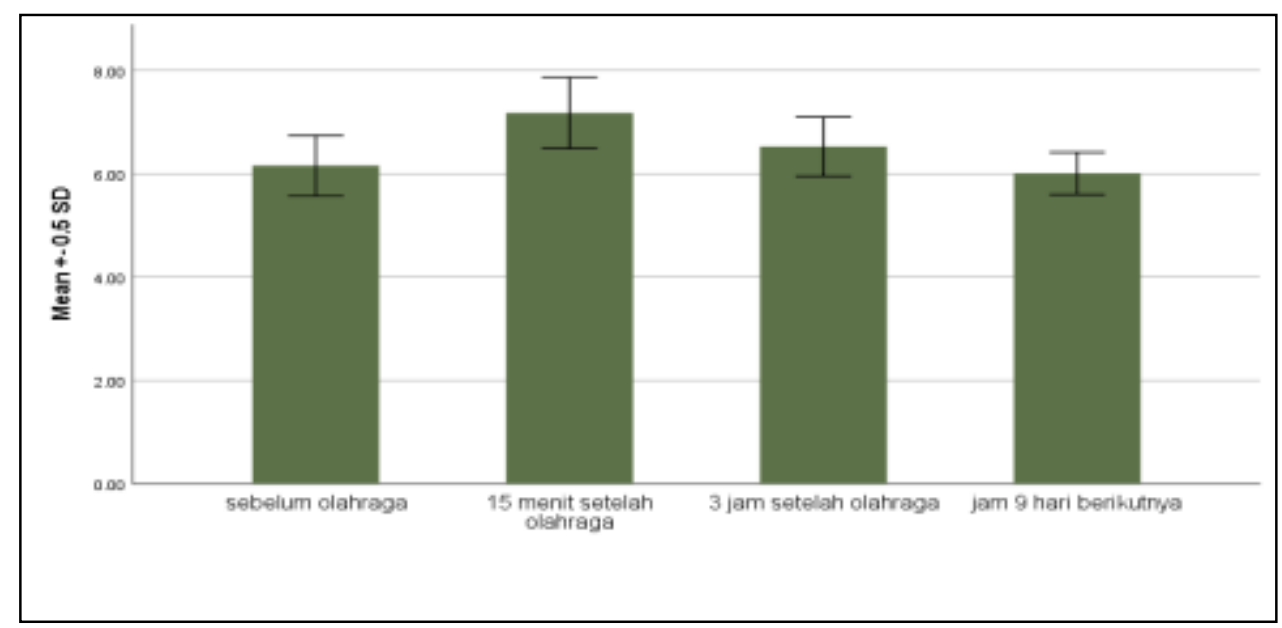

Gambar 2. The Standard Deviations for The Error Bars

Tabel 3. Analisis Deskriptif Kadar Asam Urat

\begin{tabular}{lcccc}
\hline & mean & Standar error & Lower Bound & Upper Bound \\
\hline Sebelum olahraga & 6,156 & 0,412 & 5,182 & 7,131 \\
15 menit setelah olahraga & 7,175 & 0,485 & 6,028 & 8,322 \\
3 jam setelah olahraga & 6,525 & 0,404 & 5,569 & 7,481 \\
Jam 9 hari berikutnya & 6,006 & 0,288 & 5,324 & 6,688 \\
\hline
\end{tabular}

Tabel 3 di atas menunjukkan perubahan kadar asam urat responden sebelum dan setelah olahraga. Sebelum olahraga responden memiliki rata-rata kadar asam urat sebesar 6,156 mg/dl yang menunjukkan bahwa rata-rata responden penelitian memiliki kadar asam urat yang masih dalam batas kadar normal. Pada tingkat kepercayaan 95\%, rata-rata kadar asam urat sebelum olahraga berada dalam interval 5,182 sampai dengan 7,131. Kemudian 15 menit setelah olahraga, rata-rata kadar asam urat responden mengalami kenaikan. Rata-rata kadar asam urat responden dititik ini mencapai 7,175 mg/dl yang berarti kadar asam urat telah melewati batas normal. Kadar asam urat normal pada perempuan ada dalam rentang 2-6,5 mg/dl (Darmawan et al., 2016). Hal ini menunjukkan adanya perbedaan pada kadar asam urat responden saat 15 menit setelah olahraga, dimana pada titik ini terdapat kenaikan sebesar 1,019 
$\mathrm{mg} / \mathrm{dl}$ dari sebelum olahraga. Pada tingkat kepercayaan 95\%, rata-rata kadar asam urat responden saat 15 menit setelah olahraga berada dalam interval 6,028 sampai dengan 8,322. Peningkatan pada titik ini terjadi karena saat berolahraga atau melakukan gerakan fisik akan menyebabkan kadar asam laktat mengalami peningkatan sehingga menurunkan pengeluaran asam urat dan meningkatkan kandungan asam urat dalam tubuh (Andry; Saryono; Upoyo, 2009). Hal tersebut juga diungkapkan oleh Krisnatuti et al., (1997) dimana olahraga akan menyebabkan meningkatnya asam laktat yang terbentuk dari suatu proses glikolisis (Therik, 2019). Proses glikolisis tersebut terjadi di otot dan jika otot mengalami kontraksi di dalam suatu media anaerob (media yang tidak memiliki oksigen) maka akan muncul laktat sebagai produksi akhir glikosis karena menghilangnya glikogen. Penurunan pengeluaran asam urat oleh ginjal disebabkan oleh meningkatnya kadar asam laktat dalam darah (Therik, 2019). Secara fisiologis, ginjal memiliki peran penting pada hemostasis dan ekskresi/ pengeluaran asam urat (Darmawan et al., 2016). Ginjal mengeluarkan atau mengekskresikan $2 / 3$ sampai $3 / 4$ asam urat dari dalam tubuh dan sisanya sebagian besar dikeluarkan melalui usus (Darmawan et al., 2016).

Kadar asam urat responden diukur lagi setelah beristirahat selama tiga jam. Pada titik ini, ratarata kadar asam urat mengalami penurunan sebesar $0,56 \mathrm{mg} / \mathrm{dl}$ dari titik sebelumnya. Hal tersebut menunjukkan bahwa kadar asam urat responden mengalami perubahan dan mendekati batas normal kadar asam urat. Pada tingkat kepercayaan 95\%, rata-rata kadar asam urat responden setelah beristirahat selama tiga jam, berada dalam interval 5,569 sampai dengan 7,481. Keesokan hari pada pukul 09.00 WIB, rata-rata kadar asam urat responden mengalami penurunan hingga mencapai $6,006 \mathrm{mg} / \mathrm{dl}$ yang berarti bahwa kadar asam urat responden ada dalam batas normal.

Setelah mengalami peningkatan kadar asam urat sesaat setelah berolahraga, kadar asam urat mengalami penurunan setelah beristirahat hingga sedikit lebih rendah daripada sebelum olahraga. Saat melakukan aktifitas fisik olahraga, asam laktat akan dihasilkan dan peningkatan asam laktat akan menyebabkan menurunnya ekskresi/ pengeluaran asam urat, namun peningkatan pada asam laktat tersebut hanya terjadi sementara saja dan beberapa jam kemudian asam laktat akan kembali pada kadar normal (Natania \& Malinti, 2020). Selanjutnya penurunan kadar asam urat terjadi karena aktivitas fisik olahraga memiliki pengaruh terhadap resistensi insulin (Darmawan et al., 2016). Resistensi insulin selanjutnya mempengaruhi proses ekskresi asam urat (Darmawan et al., 2016). Peningkatan aktifitas fisik akan mencegah resistensi insulin sehingga dapat meningkatkan ekskresi asam urat. Resistensi insulin tersebut akan mengakibatkan peningkatan reabsorpsi asam urat melalui sodium dependent anion cotransporter pada membran brush border tubulus proksimal ginjal atau melalui suatu perangsangan URATI (urate-anion exchanger urate transporter) (Darmawan et al., 2016). Melalui hasil analisis deskriptif tersebut, dapat disimpulkan bahwa perlakukan aktivitas fisik olahraga bulu tangkis mengakibatkan adanya respon perubahan pada kadar asam urat.

Analisis inferensia dengan menggunakan repeated measure analysis dapat digunakan untuk menguji secara global maupun marginal, bagaimana respon perubahan kadar asam urat akibat aktivitas olahraga bulu tangkis. Sebelum melakukan analisis dengan menggunakan hasil pada repeated measure analysis, terdapat dua asumsi yang harus di penuhi yaitu asumsi normalitas dan homogenitas. Hasil uji kedua asumsi ini ditampilkan pada tabel 4 dan 5 berikut:

Tabel 4. Test of Normality

\begin{tabular}{lccc}
\hline & statistic & $d f$ & Sig. \\
\hline $\begin{array}{l}\text { Standardized residual for p1 } \\
\text { (sebelum olahraga) }\end{array}$ & 0,134 & 8 & 0,200 \\
$\begin{array}{l}\text { Standardized residual for p } \\
\text { (15 menit setelah olahraga) }\end{array}$ & 0.208 & 8 & 0,200 \\
$\begin{array}{l}\text { Standardized residual for } p 3 \\
\text { (3 jam setelah olahraga) }\end{array}$ & 0,169 & 8 & 0,200 \\
$\begin{array}{l}\text { Standardized residual for p4 } \\
\text { (jam 09.00 hari berikutnya) }\end{array}$ & 0,160 & 8 & 0,200 \\
\hline
\end{tabular}

Tabel 5. Mauchly's Test of Sphericity

$\begin{array}{cccc}\text { Mauchly's W } & \text { Approx. Chi-Square } & d f & \text { Sig. } \\ 0,299 & 6,900 & 5 & 0,234\end{array}$


Jurnal Keolahragaan 9 (2), 2021 - 285

Angkit Kinasih, Ronaldo Lomi Djara, Ferry Fredy Karwur

Tabel 6. Test of within-subject effect

\begin{tabular}{cccccc}
\hline & Type III Sum of Square & $d f$ & Mean Square & $F$ & Sig. \\
Greenhouse-Geisser & 6,508 & 2,082 & 3,126 & 4,066 & 0,038 \\
\hline
\end{tabular}

Asumsi normalitas dan homogenitas terpenuhi jika hipotesis nol diterima, sehingga diharapkan nilai probabilitas hasil uji lebih besar dari taraf signifikansi alpha 0,05 . Berdasarkan hasil uji normalitas pada tabel 4 dan uji homogenitas pada tabel 5, terlihat bahwa probability value lebih dari taraf signifikansi alpha 0,05 , sehingga hipotesis nol diterima. Hal ini menunjukkan bahwa residual memenuhi asumsi normalitas dan data memiliki varians yang homogen. Setelah kedua asumsi ini terpenuhi, maka hasil yang ditunjukkan pada tabel 6 dapat diinterpretasikan. Berbeda dengan pengujian pada kedua asumsi tersebut, pada uji Greenhouse-Geisser diharapkan hasil uji memiliki nilai probabilitas yang kurang dari taraf signifikansi alpha 0,05 sehingga hipotesis nol ditolak atau hipotesis alternatif diterima. Nilai probabilitas sebesar 0,038 pada uji Greenhouse-Geisser menunjukkan bahwa hipotesis alternatif yang menyebutkan bahwa ada perbedaan rata-rata kadar asam urat pada ke-empat kelompok waktu pengukuran dapat diterima. Selanjutnya untuk melihat secara marginal perbedaan rata-rata kadar asam urat pada ke-empat waktu pengukuran maka digunakan tabel pairwise comparison berikut:

Tabel 7. Pairwise Comparison

\begin{tabular}{|c|c|c|c|c|}
\hline & $\begin{array}{l}\text { sebelum } \\
\text { olahraga }\end{array}$ & $\begin{array}{c}15 \text { menit setelah } \\
\text { olahraga }\end{array}$ & $\begin{array}{c}3 \text { jam setelah } \\
\text { olahraga }\end{array}$ & $\begin{array}{c}\text { jam } 09.00 \text { hari } \\
\text { berikutnya }\end{array}$ \\
\hline sebelum olahraga & & $\begin{array}{l}\mathrm{md}=-1,019 \\
\mathrm{pv}=0,053 \\
\text { low }=-2,053 \\
\mathrm{upp}=0,015\end{array}$ & $\begin{array}{l}\mathrm{md}=-0,369 \\
\mathrm{pv}=0,410 \\
\text { low }=-1,363 \\
\text { upp }=0,626\end{array}$ & $\begin{array}{l}\mathrm{md}=0,150 \\
\mathrm{pv}=0,513 \\
\text { low }=-0,364 \\
\text { upp }=0,664\end{array}$ \\
\hline 15 menit setelah olahraga & & & $\begin{array}{l}\mathrm{md}=0,650 \\
\mathrm{pv}=0,116 \\
\text { low }=-0,208 \\
\mathrm{upp}=1,508\end{array}$ & $\begin{array}{l}\mathrm{md}=1,169 \\
\text { pv }=0,025^{*} \\
\text { low }=0,194 \\
\text { upp }=2,143\end{array}$ \\
\hline 3 jam setelah olahraga & & & & $\begin{array}{l}\mathrm{md}=0,519 \\
\mathrm{pv}=0,116 \\
\text { low }=-0,165 \\
\mathrm{upp}=1,202\end{array}$ \\
\hline $\begin{array}{l}\text { jam } 09.00 \text { hari } \\
\text { berikutnya }\end{array}$ & & & & \\
\hline
\end{tabular}

Ket: md (mean difference), pv (probability value), low (lower bound), upp (upper bound)

Berdasarkan tabel 7, rata-rata kadar asam urat mengalami peningkatan sebesar 1,019 mg/dl saat 15 menit setelah olahraga bulu tangkis. Namun peningkatan ini tidak signifikan secara nyata yang ditunjukkan oleh probability value yang lebih besar dari 0,05 yaitu 0,053, dan confident interval yang melewati nilai nol (berkisar dari negatif ke positif). Hal ini juga terjadi pada dua waktu pengukuran setelahnya. Hal yang menarik ditunjukkan pada saat 15 menit setelah olahraga bulu tangkis dan jam 09.00 hari berikutnya, dimana pada titik ini rata-rata kadar asam urat menurun sebesar $1,169 \mathrm{mg} / \mathrm{dl}$. Penurunan ini signifikan secara nyata dengan nilai probabilitas sebesar 0,025 . Pada tingkat kepercayaan $95 \%$, rata-rata penurunan ini berkisar dari $0,194 \mathrm{mg} / \mathrm{dl}$ sampai dengan $2,143 \mathrm{mg} / \mathrm{dl}$.

Pada penelitian ini ditemukan bahwa rata-rata kadar asam urat sebelum olahraga dan jam 09.00 hari berikutnya mengalami penurunan sebesar $0,519 \mathrm{mg} / \mathrm{dl}$. Akan tetapi penurunan ini tidak signifikan secara statistik karena memiliki probability value yang lebih besar dari 0,05 yaitu 0,116 . Penurunan yang tidak signifikan ini dapat terjadi karena olahraga bulu tangkis tidak dilakukan secara rutin. Pada penelitian yang dilakukan oleh (Azhari, 2017) menunjukkan bahwa telah terjadi penurunan yang signifikan pada kadar asam urat setelah diberikan intervensi latihan bulu tangkis. Terdapat beberapa perbedaan pada penelitian ini dan penelitian yang dilakukan oleh Azhari. Subyek penelitian (Azhari, 2017) adalah PNS dan pekerja swasta yang melakukan latihan rutin bulu tangkis serta berfokus pada resiko penyakit degeneratif, yang salah satunya adalah asam urat. Penelitian ini memiliki subyek 
penelitian yang tidak rutin melakukan olahraga bulu tangkis dan lebih spesifik membahas bagaimana pengaruh olahraga bulu tangkis terhadap respon perubahan kadar asam urat.

Terdapat beberapa penelitian lain yang meneliti bagaimana pengaruh olahraga atau aktivitas fisik terhadap kadar asam urat. (Wuisantono et al., 2015) melakukan penelitian bagaimana pengaruh senam zumba terhadap terhadap kadar asam urat. Hasil pada penelitian tersebut menunjukkan bahwa aktivitas senam Zumba yang dilakukan selama satu minggu tidak memberikan perubahan yang signifikan pada kadar asam urat. Penurunan yang tidak signifikan tersebut terjadi karena tubuh tidak mempunyai waktu yang cukup untuk melakukan adaptasi fisiologis, karena adaptasi tersebut hanya berhasil apabila dilakukan dengan jangka waktu 8-10 minggu (Wuisantono et al., 2015). Penelitian yang dilakukan oleh Paul T William (2008) menyebutkan bahwa pelari nasional yang melakukan aktivitas fisik dengan intensitas yang tinggi memiliki risiko 50\% sampai $65 \%$ lebih rendah untuk terkena penyakit asam urat atau gout (Dayana \& Bahrudin, 2015). Pada penelitian (Syarifuddin et al., 2010) menemukan bahwa terdapat hubungan yang signifikan antara kadar asam urat dengan aktivitas fisik yang dilakukan pada penderita asam urat atau gout, dimana peningkatan aktivitas fisik akan menyebabkan penurunan pada kadar asam urat dalam darah. (Pusriningsih \& Panunggal, 2015) mengungkapkan bahwa terdapat hubungan yang signifikan atau bermakna antara kadar asam urat dengan aktivitas fisik yang dilakukan pada remaja laki-laki. (Astari et al., 2018) juga menyatakan bahwa terdapat hubungan yang signifikan antara kadar asam urat dengan aktivitas fisik yang dilakukan pada usia produktif.

Penelitian yang dilakukan oleh (Fauzi, 2018) mengungkapkan bahwa terdapat hubungan yang signifikan antara kadar asam urat dengan aktivitas fisik yang dilakukan, dan mayoritas responden memiliki aktivitas fisik yang berat dan sebagian besar memiliki kadar asam urat yang tinggi. Ilyas (2014) menyatakan bahwa aktivitas fisik yang berat menjadi salah satu penyebab meningkatnya kadar asam urat dalam darah karena adanya produksi asam laktat selama melakukan aktifitas. (Dayana \& Bahrudin, 2015) mengungkapkan bahwa aktivitas fisik yang dilakukan dengan intensitas sedang sampai tinggi memiliki risiko 2,56 kali lebih tinggi terhadap angka kejadian hiperurisemia atau kadar asam urat tinggi. Beberapa pendapat mengungkapkan bahwa aktivitas yang berat akan menyebabkan penyakit asam urat atau gout yang diderita semakin berat, hal tersebut ditandai dengan adanya peningkatan kadar asam urat dalam darah, sehingga dalam penelitian (Andry; Saryono; Upoyo, 2009) memberikan saran untuk yang ingin menurunkan kadar asam urat agar melakukan olahraga ringan yang teratur.

\section{SIMPULAN}

Berdasarkan hasil analisis menggunakan repeated measure dengan uji greenhouse-geisser, probabilitas menolak hipotesis nol adalah 0,038 , sehingga pada taraf signifikansi 0,05 , perlakuan bulu tangkis memberikan respon perubahan yang signifikan terhadap kadar asam urat, dimana terjadi peningkatan sesaat setelah olahraga dan kemudian turun sedikit lebih rendah daripada sebelum olahraga. Dari hasil uji marginal menggunakan pairwise comparison, terdapat perbedaan yang signifikan pada rata-rata kadar asam urat 15 menit setelah olahraga dan pada pukul 09.00 wib keesokan harinya. Hal ini berarti, konsentrasi asam urat dapat digunakan sebagai penanda metabolic fitness segera setelah aktivitas fisik. Penelitian selanjutnya dapat meneliti pengaruh beragam olahraga lain dengan derajat intensitas berbeda-beda untuk melihat respon perubahan kadar asam urat akibat olahraga tersebut. Olahraga bulu tangkis dapat menurunkan kadar asam urat yang ditandai dengan adanya penurunan sebesar $0,15 \mathrm{mg} / \mathrm{dl}$ pada jam 09.00 hari berikutnya dibandingkan dengan sebelum olahraga. Sehingga olahraga bulu tangkis dapat menjadi salah satu pilihan aktifitas fisik bagi yang ingin menurunkan kadar asam urat.

\section{DAFTAR PUSTAKA}

Agostini, L., Martinon, F., Burns, K., Mcdermott, M. F., Hawkins, P. N., \& Rg Tschopp, J. (2004). NALP3 Forms an IL-1-Processing Inflammasome with Increased Activity in Muckle-Wells Autoinflammatory Disorder. Immunity, 20, 319-325. https://doi.org/10.1016/s10747613(04)00046-9

Ames, B. N., Cathcart, R., Schwiers, E., \& Hochstein, P. (1981). Uric acid provides an antioxidant defense in humans against oxidant- and radical-caused aging and cancer: A hypothesis. Proceedings of the National Academy of Sciences of the United States of America, 78(11 II), 6858-6862. https://doi.org/10.1073/pnas.78.11.6858 
Andriani, A., \& Chaidir, R. (2016). Pengaruh Pemberian Air Rebusan Daun Salam (Syzygium Polyanthum) Terhadap Penurunan Kadar Asam Urat. Jurnal Iptek Terapan, 10(2), 112-119. https://doi.org/10.22216/jit.2016.v10i2.440

Andry; Saryono; Upoyo, A. S. (2009). Analisis Faktor-Faktor yang Mempengaruhi Kadar Asam Urat Pada Pekerja Kantor di desa Karang Turi, Kecamatan Bumiayu, Kabupaten Brebes. Jurnal Keperawatan Soedirman, 4(1), 26-31. http://jks.fikes.unsoed.ac.id/index.php/jks/article/view/219/110

Astari, R. W. D., Mirayanti, N. K. A., \& Arisusana, I. M. (2018). Faktor-Faktor yang Mempengaruhi Kadar Asam Urat Pada Usia Produktif Di Desa Nongan, Kabupaten Karangasem. BMJ, 5(2), 273-280. https://doi.org/https://doi.org/10.36376/bmj.v5i2.43

Azhari. (2017). Pengaruh Latihan Bulu Tangkis Terhadap Kadar Kolestrol, Asam Urat, Dan Glukosa Darah Di Kota Samarinda Tahun 2017. II(2), 42-50. http://r2kn.litbang.kemkes.go.id/handle/123456789/36337

Bowman, G. L., Shannon, J., Frei, B., Kaye, J. A., \& Quinn, J. F. (2010). Uric acid as a CNS antioxidant. Journal of Alzheimer's Disease, 19(4), 1331-1336. https://doi.org/10.3233/JAD2010-1330

Choi, H. K., Mount, D. B., \& Reginato, A. M. (2005). Pathogenesis of gout. Annals of Internal Medicine, 143(7), 499-516. https://doi.org/10.7326/0003-4819-143-7-200510040-00009

Conley, D. L., \& Krahenbuhl, G. S. (1980). Running economy and distance running performance of highly trained athletes. Medicine \& Science in Sports \& Exercise, 12(5), 357-360. https://doi.org/10.1249/00005768-198012050-00010

Darmawan, P. S., Kaligis, S. H. M., \& Assa, Y. A. (2016). Gambaran kadar asam urat darah pada pekerja kantor. Jurnal E-Biomedik, 4(2). https://doi.org/10.35790/ebm.4.2.2016.14615

Dayana, B., \& Bahrudin, U. (2015). Hubungan Antara Intensitas Aktivitas Fisik dan Kadar Asam Urat Serum Pada Populasi Sindrom Metabolik. Media Medika Muda, 4(4), 509-521. https://www.neliti.com/publications/139030/hubungan-antara-intensitas-aktivitas-fisik-dankadar-asam-urat-serum-pada-popula

Desideri, G., Castaldo, G., Lombardi, A., Mussap, M., Testa, A., Pontremoli, R., Punzi, L., \& Borghi, C. (2014). Is it time to revise the normal range of serum uric acid levels? European Review for Medical and Pharmacological Sciences, 18(9), 1295-1306.

Fauzi, M. (2018). Hubungan Aktivitas Fisik dengan Kadar Asam Urat di Padukuhan Bedog Trihanggo Gamping Sleman Yogyakarta. Ilmu Keperawatan. http://digilib.unisayogya.ac.id/id/eprint/437\%0A3

Feig;, D. I., Kang;, D.-H., \& Johnson, R. J. (2008). Uric acid and cardiovascular risk. N Engl J Med, 359(17), 1811-1821. https://doi.org/10.1056/NEJMra0800885

Fikri, A. (2017). Upaya Meningkatkan Kesegaran Jasmani Melalui Metode Latihan Sirkuit Dalam Pembelajaran Penjasorkes Di SMA Negeri 1 Lubuklinggau. Jurnal SPORTIF : Jurnal Penelitian Pembelajaran, 3(1), 89-102. https://doi.org/10.29407/js_unpgri.v3i1.736

Ho, R. (2014). Handbook of univariate and multivariate data analysis with IBM SPSS, second edition. In US: Taylor \& Francis Group, LLC.

Joosten, L. A. B. ., Crisan;, T. O., Bjornstad, P., \& Johnson, R. J. . (2020). Asymptomatic Hyperuricemia - A silent activator of the innate Immune system. Nat Rev Rheumatol, 16(2), 7586. https://doi.org/10.1038/s41584-019-0334-3

Laye, M. J., Nielsen, M. B., Hansen, L. S., Knudsen, T., \& Pedersen, B. K. (2015). Physical activity enhances metabolic fitness independently of cardiorespiratory fitness in marathon runners. Disease Markers, 2015, 1-11. https://doi.org/10.1155/2015/806418 


\section{Jurnal Keolahragaan 9 (2), 2021 - 288}

Angkit Kinasih, Ronaldo Lomi Djara, Ferry Fredy Karwur

Lee, P. H., Macfarlane, D. J., Lam, T., \& Stewart, S. M. (2011). Validity of the international physical activity questionnaire short form (IPAQ-SF): A systematic review. International Journal of Behavioral Nutrition and Physical Activity, 8(115). https://doi.org/10.1186/1479-5868-8-115

Martinon, F. (2008). Detection of immune danger signals by NALP3. Journal of Leukocyte Biology, 83(3), 507-511. https://doi.org/10.1189/jlb.0607362

Muthiarani, A., Lismadiana;, \& Yuniana, R. (2021). The effect of shadow training using consecutive steps and cross steps on the agility of the footwork of badminton athletes. Jurnal Keolahragaan, 9(1), 108-117. https://doi.org/10.21831/jk.v9i1.32256

Natania, N., \& Malinti, E. (2020). Hubungan Aktivitas Fisik Dengan Kadar Asam Urat Di Rw 13 Kampung Mokla, Kecamatan Parongpong. Klabat Journal of Nursing, 2(2), 17-24. https://doi.org/10.37771/kjn.v2i2.488

P2PTM Kemenkes RI. (2021). No Title. http://p2ptm.kemkes.go.id/infographic-p2ptm/hipertensi penyakit-jantung-dan-pembuluh-darah/apa-yang-dimaksud-sehat-dan-bugar

Pate, R. R., \& Kriska, A. (1984). Physiological Basis of the Sex Difference in Cardiorespiratory Endurance. Sports Medicine, 1(2), 87-89. https://doi.org/10.2165/00007256-198401020-00001

Powers, S. K., Radak, Z., \& Ji, L. L. (2016). Exercise-induced oxidative stress: past, present and future. Journal of Physiology, 594(18), 5081-5092. https://doi.org/10.1113/JP270646

Pusriningsih, S. S., \& Panunggal, B. (2015). hubungan Asupan Purin, vitamin C, dan Aktivitas Fisik Terhadap Kadar Asam urat Pada Remaja Laki-Laki. Journal of Nutrition College, 4(1), 24-29. https://doi.org/10.14710/jnc.v4i1.8617

Putra, G. I., \& Sugiyanto, F. (2016). Pengembangan pembelajaran teknik dasar bulu tangkis berbasis multimedia pada atlet usia 11 dan 12 tahun. Jurnal Keolahragaan, 4(2), 175-185. https://doi.org/10.21831/jk.v4i2.10893

Rabadán, M., Díaz, V., Calderón, F. J., Benito, P. J., Peinado, A. B., \& Maffulli, N. (2011). Physiological determinants of speciality of elite middle- and long-distance runners. Journal of Sports Sciences, 29(9), 975-982. https://doi.org/10.1080/02640414.2011.571271

Saltin, B., \& Pilegaard, H. (2002). Metabolic fitness: physical activity and health. Ugeskrift for laeger, 164(16), 2156-2162.

Syarifuddin, L. A., Taiyeb, A. M., \& Caronge, M. W. (2010). Hubungan Pola Makan dan Aktivitas Fisik dengan Kadar Asam Urat Dalam Darah Pada Penderita Asam Urat ( Gout ) di Wilayah Kerja Puskesmas Sabbangparu Kabupaten Wajo. Prosiding Seminar Nasional Biologi VI, 372381. https://ojs.unm.ac.id/semnasbio/article/view/10579/6201

Therik, K. S. S. (2019). Analisis Faktor-Faktor Yang Mempengaruhi Kadar Asam Urat Pada Pasien Di Puskesmas Naibonat. http://repository.poltekeskupang.ac.id/1062/

Waring, W. S., Convery, A., Mishra, V., Shenkin, A., Webb, D. J., \& Maxwell, S. R. J. (2003). Uric acid reduces exercise-induced oxidative stress in healthy adults. Clinical Science, 105(4), 425430. https://doi.org/10.1042/CS20030149

Wicaksono, A. (2020). Aktivitas Fisik Yang Aman Pada Masa Pandemi Covid-19. Jurnal Ilmu Keolahragaan Undiksha, 8(1), 10-15. https://doi.org/http://dx.doi.org/10.23887/jiku.v8i1.28446

Wuisantono, D. C., Rattu, J. A. M., \& Polii, H. (2015). Pengaruh Senam Zumba Terhadap Kadar Asam Urat Pada Mahasiswi Fakultas Kedokteran Angkatan 2014. Jurnal E-Biomedik, 3(2), 651655. https://doi.org/10.35790/ebm.3.2.2015.8860 